\title{
Analisis Faktor-faktor Perubahan Design Terhadap Proyek Konstruksi Pelebaran Jalan Tol Jakarta-Merak (Area Cikupa)
}

\author{
Yunita Dian Suwandari', Oties T.Tsarwan ${ }^{2}$ \\ ${ }^{1,2}$ Civil Engineering Department, Faculty of Engineering, \\ Mercu Buana University, \\ Jakarta, Indonesia 11480, \\ yunita.dian@mercubuana.co.id; \\ oties@mercubuana.co.id
}

\begin{abstract}
In every project, job changes are always happening and almost unavoidable. One of the factors that influence job change is a design change. This study analyzes the design changes that have caused delays in the JakartaMerak toll road widening project in the Cikupa areacollecting data using literature studies and questionnaires with five Linkert scales. The analysis used SPSS version 22. The research finding is five variables of design changes and changes due to the land's location to be used as a project, which are the leading causes of changes in this project's design.
\end{abstract}

Keywords: Toll Road; Construction; Project Delay; Design Changes; SPSS.

Abstrak - Pada setiap proyek, perubahan pekerjaan selalu terjadi dan hampir tidak dapat dihindari. Salah satu faktor yang mempengaruhi perubahan pekerjaan adalah perubahan design. Penelitian bertujuan untuk menganalisis mengenai perubahan design yang menyebabkan keterlambatan proyek pelebaran jalan tol Jakarta-Merak di area Cikupa. Pengumpulan data menggunakan studi literatur dan kuisioner dengan lima skala linkert. Analisis mengunakan SPSS versi 22. Hasil penelitian ini adalah terdapat lima variabel perubahan design dan perubahan akibat lokasi tanah yang akan digunakan sebagai proyek menjadi penyebab utama perubahan design proyek ini.

Kata kunci: Jalan Tol; Konstruksi; Keterlambatan proyek; Perubahan Design; SPSS.

\section{PENDAHULUAN}

Perubahan design menjadi hal yang umum pada proyek konstruksi. Perubahan ini sering menyebabkan keterlambatan waktu dan juga pembengkakan biaya. (Boon et al., 2015)
Perubahan design menyebabkan rework dan rework tersebut menyebabkan pekerjaan terhenti dan hilangnya produktivitas pekerjaan. Akibat dari terhentinya pekerjaan menimbulkan jadwal penyelesaian proyek yang terlambat dan kenaikan biaya (Yap et al., 2016)

Perubahan design merupakan risiko yang memiliki dampak yang tinggi terhadap keterlambatan proyek risiko. Ini bisa terjadi karena adanya permintaan owner maupun permintaan buyer pada owner (Kristiana, 2017)

Kurangnya komunikasi diantara stakeholder menjadi salah satu penyebab utama adanya perubahan design, padahal perubahan design ini dapat menyebabkan perbedaan biaya pada range 5\%-40\% (Aslam et al., 2019)

Perubahan design pada proyek konstruksi selalu tidak dapat dihindarkan dan menyebabkan gangguan pada performance proyek.Owner menjadi penyebab utama sebagai pihak yang mempengaruhi perubahan design(Yana et al., 2015)

Terjadinya keterlambatan proyek di Surabaya diakibatkan perubahan design oleh pemilik serta kekeliruan design oleh konsultan perencana (Bruno, 2019)

Perubahan design oleh owner pada proyek jalan raya di Manado menjadi salah satu penyebab keterlambatan proyek. Pentingnya komunikasi yang baik antara kontraktor, konsultan dan owner supaya proyek berjalan dengan baik (Palulun et al., 2017)

Perubahan design pada design struktur atap pembangunan gedung kantor DPRD Riau menimbulkan dampak keterlambatan waktu dan peningkatan biaya sebesar 29\% (Sandyavitri, 2008.)

Pada proyek jalan tol Jakarta-Merak (area Cikupa), terdapat keterlambatan proyek yang disebabkan berbagai faktor seperti tenaga kerja, peralatan, material, perubahan design, lingkungan, organisasi, kontrak dan pelayanan, kontrol dan pengawasan (Lois, 2018) 
Penelitian ini bertujuan untuk mengeksplorasi lebih lanjut faktor-faktor perubahan design yang mempengaruhi keterlambatan proyek pada proyek konstruksi jalan tol Jakarta-Merak (area Cikupa)

\section{METODE}

Untuk menjawab perumusan masalah, penelitian ini menggunakan metode kualitatif dan kuantitatif. Metode kualitatif digunakan untuk mengeksplore riset, teknik wawancara digunakan untuk mendapatkan data secara mendalam. Metode Kuantitatif dengan menggunakan kuisioner. Pada kuisioner tersebut menggunakan skala linkert pada Tabel 1.

Tabel 1. Contoh kuisioner dengan 5 skala lingkert

\begin{tabular}{ccccc}
\hline 1 & 2 & 3 & 4 & 5 \\
\hline $\begin{array}{c}\text { Sangat } \\
\text { tidak } \\
\text { setuju }\end{array}$ & $\begin{array}{c}\text { Tidak } \\
\text { Setuju }\end{array}$ & Netral & Setuju & $\begin{array}{c}\text { Sangat ti- } \\
\text { dak setuju }\end{array}$ \\
\hline
\end{tabular}

\section{HASIL DAN ANALISA}

Kuisioner tahap 1 diberikan kepada 5 orang pakar yang mempunyai pengalaman lebih daro 3 tahun dalam bidang konstruksi terutama kontruksi jalan raya. Adapun hasilnya terdapat 5 indikator yang disetujui untuk digunakan sebagai indikator survey lanjutan. Tabel 2 menunjukkan hasil tahap 1.

Tabel 2. Variabel perubahan design

\begin{tabular}{|c|c|c|}
\hline Variabel & Indikator & Sub Indikator \\
\hline \multirow{6}{*}{$\begin{array}{l}\text { Faktor } \\
\text { Perubahan } \\
\text { Design }\end{array}$} & $\mathrm{X} 1$ & $\begin{array}{l}\text { Perubahan desain yang } \\
\text { terlalu signifikan }\end{array}$ \\
\hline & $\mathrm{X} 2$ & $\begin{array}{l}\text { Terjadi perubahan desain } \\
\text { oleh } O w n e r \text { saat pelaksanaan }\end{array}$ \\
\hline & $\mathrm{X} 3$ & $\begin{array}{l}\text { Kesalahan desain yang } \\
\text { dibuat oleh perencana }\end{array}$ \\
\hline & X4 & $\begin{array}{l}\text { Ketidak-akuratan disain } \\
\text { yang membutuhkan review } \\
\text { desain }\end{array}$ \\
\hline & $\mathrm{X} 5$ & $\begin{array}{l}\text { Perubahan akibat lokasi } \\
\text { tanah yang akan digunakan } \\
\text { sebagai proyek }\end{array}$ \\
\hline & X6 & $\begin{array}{l}\text { Metode konstruksi/ } \\
\text { pelaksanaan kerja yang } \\
\text { salah/tidak lengkap }\end{array}$ \\
\hline
\end{tabular}

Sumber: Olahan Penulis

Tahap selanjutnya kuisioner diberikan kepada 48 orang responden yang terlibat dalam proyek Proyek pelebaran jalan tol Tangerang-Merak dengan kriteria masa kerja sesuai tabel 3.
Tabel 3. Kategori pengalaman bekerja

\begin{tabular}{ccc}
\hline $\begin{array}{c}\text { Pengalaman bekerja } \\
\text { di proyek sejenis }\end{array}$ & Frekuensi & $\begin{array}{c}\text { Persentase } \\
(\%)\end{array}$ \\
\hline $1 \mathrm{~s} / \mathrm{d} 5$ th & 37 & 77,3 \\
\hline $6 \mathrm{~s} / \mathrm{d} 10$ th & 9 & 18,7 \\
\hline $11 \mathrm{~s} / \mathrm{d} 15$ th & 1 & 2 \\
\hline $16 \mathrm{~s} / \mathrm{d} 20$ th & 1 & 2 \\
\hline Jumlah & 48 & 100 \\
\hline
\end{tabular}

Sumber: Olahan Penulis

Dari 48 sampel penelitian yang diperoleh, maka dilakukan uji validitas dan reliabilitas terhadap setiap variabel. Uji validitas ini dilakukan dengan menggunakan bantuan software SPSS Versi 22.

Tabel 4. Hasil Analisis Deskriptif

\begin{tabular}{cccccccc}
\hline & N & Min & Max & Sum & Mean & $\begin{array}{c}\text { Std. De- } \\
\text { viation }\end{array}$ & $\begin{array}{c}\text { Vari- } \\
\text { ance }\end{array}$ \\
\hline X1 & 48 & 1 & 5 & 191 & 0,193056 & .812 & .659 \\
X2 & 48 & 1 & 5 & 177 & 0,172917 & .803 & .645 \\
X3 & 48 & 2 & 5 & 197 & 04.10 & .928 & .861 \\
X4 & 48 & 2 & 5 & 197 & 04.10 & .928 & .861 \\
X5 & 48 & 2 & 5 & 199 & 04.15 & .967 & .936 \\
X6 & 48 & 1 & 5 & 172 & 03.58 & 1.028 & 1.057 \\
\hline
\end{tabular}

Sumber: Olahan Penulis

Pada tabel 4 didapat $x 5$ yaitu Perubahan akibat lokasi tanah yang akan digunakan sebagai proyek 4.15

Tabel 5. Uji Validitas

\begin{tabular}{|c|c|c|c|c|c|c|c|c|}
\hline & & $\mathrm{x} 1$ & $\times 2$ & $\times 3$ & $\times 4$ & $\times 5$ & $x 6$ & $\begin{array}{c}\text { Skor_T } \\
\text { otal }\end{array}$ \\
\hline \multirow{3}{*}{$\times 1$} & \begin{tabular}{|l|} 
Pearson \\
Correlation \\
\end{tabular} & 1 & $.512^{\prime \prime}$ & $.427^{\prime \prime}$ & $.427^{\prime \prime}$ & .248 & $474^{\prime \prime}$ & $.575^{\prime \prime}$ \\
\hline & Sig. (2-tailed) & & .000 & .003 & .003 & .090 & .001 & .000 \\
\hline & $\mathrm{N}$ & 48 & 48 & 48 & 48 & 48 & 48 & 48 \\
\hline \multirow{3}{*}{$\times 2$} & \begin{tabular}{|l|} 
Pearson \\
Correlation \\
\end{tabular} & .512 & 1 & .045 & .045 & .142 & $.561^{\prime \prime}$ & $.610^{\prime \prime}$ \\
\hline & Sig. (2-tailed) & .000 & & .763 & .763 & .335 & .000 & .001 \\
\hline & $N$ & 48 & 48 & 48 & 48 & 48 & 48 & 48 \\
\hline \multirow{3}{*}{$\times 3$} & \begin{tabular}{|l|} 
Pearson \\
Correlation
\end{tabular} & 427 & .045 & 1 & $1.000^{\circ}$ & $.552^{\prime \prime}$ & .225 & $.538^{\prime \prime}$ \\
\hline & Sig. (2-tailed) & .003 & .763 & & .000 & .000 & .124 & .000 \\
\hline & $N$ & 48 & 48 & 48 & 48 & 48 & 48 & 48 \\
\hline \multirow{3}{*}{$\times 4$} & \begin{tabular}{|l|} 
Pearson \\
Correlation
\end{tabular} & .427 & .045 & $1.000^{-1}$ & 1 & $.552^{\prime \prime}$ & .225 & $.538^{\prime \prime}$ \\
\hline & Sig. (2-tailed) & .003 & .783 & .000 & & .000 & .124 & .000 \\
\hline & $\mathrm{N}$ & 48 & 48 & 48 & 48 & 48 & 48 & 48 \\
\hline \multirow{3}{*}{$\begin{array}{l}\times 5 \\
6\end{array}$} & \begin{tabular}{|l|} 
Pearson \\
Correlation \\
\end{tabular} & .248 & .142 & $.552^{\prime \prime}$ & $.552^{\prime \prime}$ & 1 & $.383^{\prime \prime}$ & $.600^{\circ}$ \\
\hline & Sig. (2-tailed) & .090 & .335 & .000 & .000 & & .007 & .000 \\
\hline & $\mathrm{N}$ & 48 & 48 & 48 & 48 & 48 & 48 & 48 \\
\hline \multirow{3}{*}{$\times 6$} & \begin{tabular}{|l|} 
Pearson \\
Correlation
\end{tabular} & .474 & $.561^{\prime \prime}$ & .225 & .225 & $.383^{\prime \prime}$ & 1 & $.834^{\prime \prime}$ \\
\hline & Sig. (2-tailed) & .001 & .000 & .124 & .124 & .007 & & .000 \\
\hline & $\mathrm{N}$ & 48 & 48 & 48 & 48 & 48 & 48 & 48 \\
\hline \multirow{3}{*}{$\begin{array}{l}\text { Sko } \\
\text { r_T } \\
\text { otal }\end{array}$} & \begin{tabular}{|l|} 
Pearson \\
Correlation \\
\end{tabular} & .575 & $.610^{\circ}$ & $.538^{\prime \prime}$ & $.538^{\prime \prime}$ & $.600^{\circ}$ & $834^{\prime \prime}$ & 1 \\
\hline & \begin{tabular}{|l|} 
Sig. (2-tailed) \\
\end{tabular} & .000 & .001 & .000 & .000 & .000 & .000 & \\
\hline & $N$ & 48 & 48 & 48 & 48 & 48 & 48 & 48 \\
\hline
\end{tabular}

Sumber: Olahan Penulis 
Dari hasil Analisa tabel 5 Total Correlation yaitu X5 $=1.000>$ dari nilai $r$-tabel $=0.284$, maka dapat disimpulkan bahwa indikator tersebut dinyatakan valid.

Tabel 6. Uji Reabilitas

\begin{tabular}{ccccc}
\hline Variabel & r-tabel & $\begin{array}{c}\text { Cronbach's } \\
\text { Alpha }\end{array}$ & $\begin{array}{c}\text { N of } \\
\text { Items }\end{array}$ & Keterangan \\
\hline $\begin{array}{c}\text { Faktor } \\
\text { Perubahan } \\
\text { Design }\end{array}$ & 0,197222222 & 0,55 & 6 & Reliabel \\
\hline
\end{tabular}

Sumber: Olahan Penulis

Hasil Analisa uji realibilitas didapat $r$ Hasil uji reliabilitas didapat nilai Cronbach's Alpha sebesar rata-rata lebih dari nilai $\mathrm{r}$ tabel pada pengujian validitas $>0.284$. Maka dapat disimpulkan bahwa instrumen dalam penelitian ini reliabel atau konsisten.

Dari analisa data maka beberapa rekomendasi untuk mengatasi masalah perubahan design adalah sebagai berikut:

1. Diperlukan pengambilan keputusan perubahan design secara cepat di awal proyek apabila kondisi di lapangan berbeda dengan perencanaan.

2. Pentingnya perencanaan proyek secara detil dan terencana untuk menghindari permasalahan perubahan design yang dapat menyebabkan keterlambatan proyek.

3. Pekerjaan kritis harus pertama kali diperhatikan apabila terjadi perubahan design untuk menghindari keterlambatan pekerjaan lain.

\section{KESIMPULAN}

Terdapat enam faktor penyebab perubahan design pada proyek pelebaran jalan tol Jakarta-Merak (area Cikupa). Perubahan akibat lokasi tanah yang akan digunakan pada proyek menempati posisi tertinggi sebagai penyebab perubahan design proyek tersebut. keterlambatan proyek tersebut. Dampak perubahan design ini membuat jadwal penyelesaian proyek mundur. Pentingnya pengambilan keputusan dengan segera di awal proyek terhadap perubahan design sangat membantu dalam menanggulangi keterlambatan proyek. Penelitian ini terbatas pada proyek pelebaran jalan tol Jakarta-Merak (area Cikupa), sehingga tidak dapat digeneralisir untuk proyek konstruksi yang lain. Penelitian untuk variabel perubahan design terhadap proyek konnstruksi yang lain sangat dimungkinkan sebagai pengembangan hasil penelitian ini.

\section{DAFTAR PUSTAKA}

Aslam, M., Baffoe-Twum, E., \& Saleem, F. (2019). Design Changes in Construction Projects - Causes and Impact on the Cost. Civil Engineering Journal, 5(7), 1647-1655. https://doi.org/10.28991/cej2019-03091360
Boon, J., Yap, H., Tunku, U., Rahman, A., Abdul-rahman, H., \& Wang, C. (2015). Impacts Of Design Changes on Construction Project Performance : Insights From A Literature Review. November.

Bruno, L. (2019). Faktor - Faktor Yang Mempengaruhi Keterlambatan Proyek Konstruksi di Surabaya. Journal of Chemical Information and Modeling, 53(9), 1689-1699. https://doi.org/10.1017/ CBO9781107415324.004

Kristiana, R. (n.d.). Identifikasi Penyebab Risiko Keterlambatan Proyek Konstruksi Bangunan Gedung Tinggi Hunuian ( Studi Kasus : Proyek Pembangunan Condotel Dan Apartemen Bhuvana Resort Ciawi , Bogor ).

Lois, George (2018) Analisis Faktor Yang Berpengaruh Terhadap Keterlambatan Proyek Pelebaran Jalan Tol Tangerang - Merak \& Simpang Susun Cikupa Paket 2. S1 Thesis, Universitas Mercu Buana Jakarta

Palulun, Y., Pratasis, Pi. A. k, Mangare, J. B., \& Manado, R. (2017). Keterlambatan Pada Proyek Jalan Di ( Provinsi Sulawesi Utara ). Jurnal Sipil Statik Vol. 5 No. 7, 5(7), 451-464.

Sandyavitri, A. (2008.). Terhadap Waktu Dan Biaya Pekerjaan Konstruksi. 9(i), 57-70.

Yana, A. A. G. A., Rusdhi, H. A., \& Wibowo, M. A. (2015). Analysis of factors affecting design changes in construction project with Partial Least Square (PLS). Procedia Engineering, 125, 40-45. https://doi.org/10.1016/j.proeng.2015.11.007

Yap, J. B. H., Abdul-Rahman, H., \& Wang, C. (2016). A Conceptual Framework for Managing Design Changes in Building Construction. MATEC Web of Conferences, 66. https://doi.org/10.1051/ matecconf/20166600021 